\title{
Barriers to M-commerce Adoption in Developing Countries - A Qualitative Study among the Stakeholders of Bangladesh
}

\author{
Mohammed Mizanur Rahman \\ School of Business, University of Western Sydney \\ Parramatta, New South Wales, 2150, Australia \\ Email: mizan.rahman@uws.edu.au,mizan1214@yahoo.com.au
}

\begin{abstract}
The purpose of this qualitative study is to explore the key factors that act as a barrier to m-commerce (e-commerce through mobile phone or any wireless device) adoption in developing countries, and to investigate the ways to overcome these barriers. 27 face to face in-depth interviews were conducted among the participants who were classified as bankers, solution providers, telcos, retailers and government official. Lack of literacy, trust and conflict of interest between telcos and banks were found to be the major barriers to the adoption of m-commerce in Bangladesh. The research output can help in the design of a long term policy to build up a large and sustainable m-commerce enabled society.
\end{abstract}

Keywords: M-commerce, E-commerce, Barriers, Qualitative study, Bangladesh,

\section{Introduction}

There are a number of variations in the definition of m-commerce. Many scholars considered $\mathrm{m}$ commerce to be mobile e-commerce. ${ }^{1}$ Smith $^{2}$ defined $\mathrm{m}$-commerce as the buying and selling of goods and services through wireless handheld devices such as cellular phones and Personal Digital Assistants (PDA). According to others $\mathrm{m}$-commerce is the exchange of goods, services and information using mobile Information and Communication Technology (ICT). ${ }^{3}$

M-commerce is a rapidly growing market, especially in recent years and there are signs that this growth will continue. The widespread penetration of mobile phone coupled with some of its key characteristics including versatility, portability, personalized, 24/7 connectivity and ease of use, has made m-commerce a trading tool with huge potential for the global marketplace. According to Gartner research, ${ }^{4}$ mobile payment transaction worldwide has reached $\$ 105.9$ billion in 2011 and is predicted to be $\$ 617$ billion by 2016 . Mobile payment users worldwide will exceed 2.5 billion in 2015, a 40\% increase from 1.8 billion in $2011 .^{5}$ Today mobile phones are not simply being used for conversation only, but $40 \%$ of subscribers are accessing different mobile services such as
SMS, mobile internet, games, music, video, news and sports. ${ }^{6}$ Location tracking of goods and people is also one of the latest applications of $\mathrm{m}$ commerce. Online retailers have started to realize the potential of m-commerce market, with $48 \%$ of them already having developed mobile optimized m-commerce site. ${ }^{7}$ Figure1, based upon the work of two separate studies (see Refs. 8 \& 9), gives an overview of different types of m-commerce applications.

The number of mobile phone subscribers worldwide surpassed 6 billion in 2011, with three quarters of them coming from developing countries. ${ }^{10}$ The number of the mobile phone users in developing countries provides many opportunities for the exploration of an m-commerce market in these regions. However mobile broadband, the key technology of m-commerce, is highly adopted in developed countries, accounting for 701 million subscribers compared to 484 million in developing world. ${ }^{10}$ Understandably, developing countries fall behind the developed world in utilizing the power and potential of $\mathrm{m}$ commerce. Mobile banking and shopping, mobile advertising, mobile ticketing, mobile movies and videos are commonly used applications in 
developed countries, however in the developing world mobile phones are mainly used as tools of personal communication.

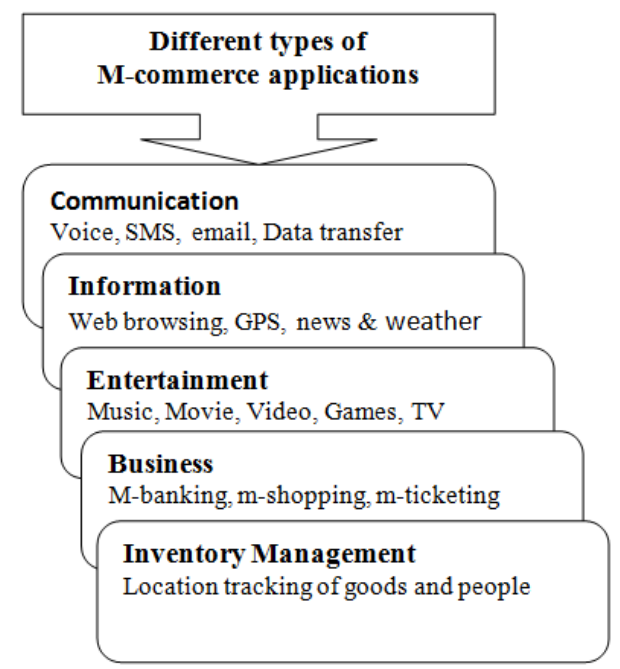

Figure 1: Applications of m-commerce, complied from two sources $8 \& 9$

M-commerce is an advanced and fast growing technology which has many barriers that are unlike those of other new technologies. ${ }^{11}$ These barriers need to be identified as they will affect the steady adoption of m-commerce applications. ${ }^{12}$ Bangladesh has been chosen as the location for this research due to its developing country status and its substantial mobile phone penetration, reported as $65 \%$ ( 98.5 million) by February 2013. ${ }^{13}$ The purpose of this paper is to investigate the barriers to $\mathrm{m}$-commerce adoption in developing countries and to find the ways to overcome those barriers. The main research question set for this study is as follows:

What are barriers to m-commerce adoption in developing countries?

Literature on m-commerce adoption will be reviewed in the next section followed by the research method, results and implications, and conclusion respectively. The last section will address the limitations of the current research and pathways for future research.

\section{Literature Review}

In the last twelve years a large number of research papers have been published that studied the key factors of m-commerce/e-commerce adoption in both developed and developing countries. Papers published before 2000 were not reviewed because of the newness and rapidly changing nature of $\mathrm{m}$ commerce technology. Prior studies frequently focused on the factors that positively influence the adoption of m-commerce. Perceived usefulness (PU) and perceived ease of use (PEOU) have been identified as major contributing factors for $\mathrm{m}$ commerce adoption worldwide. ${ }^{14-27}$ However perceived usefulness was not found to be significant in Bangladesh and Sub-Saharan Africa by some studies. $^{28 \& 29}$

Numerous studies also found little or no significant impact of perceived ease of use in the adoption of m-commerce. ${ }^{29-42}$ Research revealed that there are many other factors that affect m-commerce adoption positively such as attitude ( see Refs. 14, $17,19,25,33,38,41,43,44)$, subjective norm (see Refs. $24,25,35 \& 37$ ) social influence (see Refs. $22,29,30,32,35,36,45 \& 46$ ), self efficacy (see Refs. 25, 28, 36, 37), facilitating condition (see Refs. 14, 22, 25, 36, $41 \& 48$ ), effort expectancy (see Refs. 45, 48 \& 49),performance expectanc, ${ }^{47-49}$ job relevance, ${ }^{24} \& 39$ reputation, ${ }^{42} \& 50$ perceived credibility, ${ }^{14}$ experience (see Refs. 17, 24, 44 \& 4851), mobility, ${ }^{52}$ knowledge, ${ }^{21,53-55}$ compatibility (see Refs. $16,31,34,35,38 \& 52)$, convenience, ${ }^{16,56,57}$ perceived enjoyment (see Refs. 31, 35, 40 \& 58), perceived playfulness, ${ }^{17}$ quality (see Refs. 17, 36, $39,50 \& 51)$ and speed. ${ }^{16,21 \& 57}$

Little research has addressed the barriers that have negative impact in the adoption of $\mathrm{m}$-commerce. Perceived risk has been identified as among the major barriers of m-commerce adoption effecting the penetration negatively (see Refs. 25, 34, 37, 38, $42,47 \& 57)$. Consumers are highly concerned about their privacy and security, if not assured that would deter m-commerce penetration. The effect of perceived security and privacy was found to be significant in Bangladesh from consumer's perspective. $^{28,33}$ Lack of trust was found to be another major barrier to m-commerce adoption. Luo et. al. ${ }^{47}$ validated the negative correlation between trust and perceived risk; meaning lack of trust poses a high risk to the adoption of $\mathrm{m}$-commerce. Various issues are involved with trust such as user's experience, poor relationship, bad reputation, stakeholder's unethical business practice and risk (see Refs. 47, 51, 60 \& 61). All these issues need to be addressed when dealing with trust. Perceived cost acts as a barrier to mcommerce adoption as higher cost lowers the user's intention to use m-commerce services (see Refs. $17,28,32 \& 38)$. The effect of anxiety has also been found to be negative, more anxiety leads to less adoption, to mobile shopping adoption in Taiwan. $^{62}$ Venkatesh et. al. ${ }^{49}$ found negative relationship between anxiety and the intention to use IT adoption. Some other factors, although rarely studied, were found to have been acted as a barrier to m-commerce adoption such as 

complexity, ${ }^{15,22 \& 59}$ slow connection, ${ }^{57}$ and limited
capacity.

There has been little research that has explored the barriers to $\mathrm{m}$-commerce adoption in developing countries. The majority of the authors have studied the barriers to m-commerce adoption in developed countries from the user's perspective; relying on quantitative methods (for example Refs. 14, 15, 28, $29,30,32,33,34,53 \& 56)$. Very few researchers have studied these barriers from the stakeholder's perspective using qualitative methods. As the qualitative methodology provides a deeper and more detailed understanding on the subject than the quantitative approach, ${ }^{63}$ this study used this method in exploring the key barriers to commerce adoption in developing countries.

\section{Research method}

M-commerce is a new concept in Bangladesh and people have not yet realized the benefits of using this new technology. Studying the barriers to $\mathrm{m}$ commerce adoption in Bangladesh will assist in the development of an in-depth understanding of the key issues and challenges to its rapid uptake. Qualitative research has been chosen as it allows the researcher to gain better understanding of the problem and to identify any phenomena, patterns, behaviour and attitudes. ${ }^{67}$ This qualitative research relied on analyzing textual data from interviews rather than numerical data of survey research. ${ }^{68}$

\subsection{Sample}

It is usual that small and selective samples are used in qualitative research as it requires in-depth analysis of a large volume of data. ${ }^{69}$ For this project 27 face to face in-depth interviews were conducted to build on the preliminary insights into what people of different social categories think and believe about m-commerce. Initially it was not known how many interviews would be required to explore the research objective, but the intention was to carry on until similar and repetitive responses were gathered on the subject matter. ${ }^{64}$ Respondents from different sub categories who were actively involved in the $\mathrm{m}$-commerce arena were the target participants during the interviews. Convenience sampling was used to select the participants, who were later classified as solutions providers, telcos, banks, government officials and retailers. All the participants were assured of their confidentiality and anonymity.

\subsection{Data Analysis}

As the current research is more exploratory than confirmatory in nature, content analysis was chosen to analyze the interview transcript. ${ }^{70}$ Qualitative content analysis is defined as "a research method for the subjective interpretation of the content of text data through the systematic classification process of coding and identifying themes or patterns". ${ }^{\text {. }}$ p.1278

Nvivo software was used for the analysis, especially during coding and annotating. All the transcripts were thoroughly reviewed and then coded by organizing key words/phrase under different nodes, to uncover the key pattern/themes. ${ }^{70}$ Each node was then carefully reviewed to look for any similarities and differences in the argument raised around various issues/factors. Obviously not all the participants agreed on the same issue or concept. They varied in their ideas, thinking and reasoning. The factor/barriers with strong arguments, supported by many, were identified as the major barriers to $\mathrm{m}$ commerce adoption. In contrast, the factors/barriers justified by weak arguments and with less support were identified as having minor impact to $\mathrm{m}$ commerce adoption in Bangladesh.

\section{Results and Implications}

\subsection{Demography}

The participant's demographic information is presented in table 1. All the participants were stakeholders of m-commerce, being actively involved in m-commerce business either directly or indirectly. They were categorized as telcos, bankers, solution providers, retailers and government officials. Among the twenty seven interviewees thirteen were retailers, five telco's employees, four from banks, four from solution providers and one government official. Although a large number of participants were retailers, individuals who are not usually highly qualified and work as agents on behalf of a telco, their contribution in the study was found to be minimal. In most cases their answers were recorded without sufficient explanation and justification; normally short reply that answers what rather than why. They possessed practical experience in dealing with telcos, and that experience was found to be an important information source for analyzing some major issues. 
Table 1: Demographic information

\begin{tabular}{|c|c|c|c|}
\hline $\begin{array}{l}\text { Interviewee's } \\
\text { Identity } \\
\text { (anonymous) }\end{array}$ & Brief introduction about the organization & $\begin{array}{l}\text { Interviewee's } \\
\text { position }\end{array}$ & Qualification \\
\hline Telco 1 & $\begin{array}{l}\text { One of the largest mobile Operators in } \\
\text { Bangladesh }\end{array}$ & M-commerce manager & Highly educated \\
\hline Telco 2 & $\begin{array}{l}\text { One of the largest mobile Operators in } \\
\text { Bangladesh }\end{array}$ & $\begin{array}{l}\text { Head of business development \& } \\
\text { financial services }\end{array}$ & Highly educated \\
\hline Telco 3 & Mobile operator in Bangladesh & Manager of m-commerce division & Highly educated \\
\hline Telco 4 & Mobile operator in Bangladesh & Manager responsible for $\mathrm{m}$-commerce & Highly educated \\
\hline Telco 5 & Mobile operator in Bangladesh & Head of distribution & Highly educated \\
\hline Banker 1 & $\begin{array}{l}\text { Private bank - received permission to run } \\
\text { mobile banking at the time of interview }\end{array}$ & Head of alternate/mobile banking & Highly educated \\
\hline Banker 2 & $\begin{array}{l}\text { Private bank - received permission to run } \\
\text { mobile banking at the time of interview }\end{array}$ & $\begin{array}{l}\text { Assistant vice president of mobile } \\
\text { banking }\end{array}$ & Highly educated \\
\hline Banker 3 & $\begin{array}{l}\text { Private bank - But did not received permission } \\
\text { to run mobile banking at the time of interview }\end{array}$ & Head of kishoreganj (district) branch & Highly educated \\
\hline Banker 4 & $\begin{array}{l}\text { Public bank - But did not receive permission } \\
\text { to run mobile banking at the time of interview }\end{array}$ & $\begin{array}{l}\text { Manager of IT section, Main branch, } \\
\text { Dhaka }\end{array}$ & Highly educated \\
\hline Solution provider 1 & $\begin{array}{l}\text { Develop software and application for mobile } \\
\text { banking services }\end{array}$ & Assistant general manager & Highly educated \\
\hline Solution provider 2 & $\begin{array}{l}\text { Develop software and application for mobile } \\
\text { banking services }\end{array}$ & $\begin{array}{l}\text { Head of project management and IT } \\
\text { services }\end{array}$ & Highly educated \\
\hline Solution provider 3 & $\begin{array}{l}\text { Develop software and application for mobile } \\
\text { banking services }\end{array}$ & CEO & Highly educated \\
\hline Solution provider 4 & $\begin{array}{l}\text { Conduct research in the field of mobile } \\
\text { commerce, on behalf of a private university }\end{array}$ & $\begin{array}{l}\text { Professor of a private university, } \\
\text { Bangladesh }\end{array}$ & Highly educated \\
\hline Govt. official & Government's regulatory body & Chairman & Highly educated \\
\hline Retailer 1 & $\begin{array}{l}\text { Shop (in Dhaka city) for mobile recharge \& } \\
\text { utility billing through m-billing services }\end{array}$ & Shop owner & $\begin{array}{l}\text { Moderate } \\
\text { educated }\end{array}$ \\
\hline Retailer 2 & $\begin{array}{l}\text { Shop (in a rural area) for mobile recharge } \& \\
\text { utility billing through m-billing services }\end{array}$ & Shop owner & Lower educated \\
\hline Retailer 3 & $\begin{array}{l}\text { Shop (in Chittagong city) for mobile recharge } \\
\& \text { utility billing through m-billing }\end{array}$ & Shop owner & Lower educated \\
\hline Retailer 4 & $\begin{array}{l}\text { Shop (in a rural area) for mobile recharge \& } \\
\text { utility billing through m-billing services }\end{array}$ & Shop owner & $\begin{array}{l}\text { Moderate } \\
\text { educated }\end{array}$ \\
\hline Retailer 5 & $\begin{array}{l}\text { Shop (in a rural area) for mobile recharge \& } \\
\text { utility billing through m-billing services }\end{array}$ & Employee & Lower educated \\
\hline Retailer 6 & $\begin{array}{l}\text { Shop (in a rural area) for mobile recharge } \& \\
\text { utility billing through m-billing services }\end{array}$ & Shop owner & Lower educated \\
\hline Retailer 7 & $\begin{array}{l}\text { Shop (in a rural area) for mobile recharge } \& \\
\text { utility billing through m-billing services }\end{array}$ & Shop owner & $\begin{array}{l}\text { Moderate } \\
\text { educated }\end{array}$ \\
\hline Retailer 8 & $\begin{array}{l}\text { Shop (in Dhaka City) for mobile recharge \& } \\
\text { utility billing through m-billing services }\end{array}$ & Shop owner & $\begin{array}{l}\text { Moderate } \\
\text { educated }\end{array}$ \\
\hline Retailer 9 & $\begin{array}{l}\text { Shop (in a district town ) for mobile recharge } \\
\& \text { utility billing through m-billing }\end{array}$ & Employee & Lower educated \\
\hline Retailer 10 & $\begin{array}{l}\text { Shop (in a district town) for mobile recharge \& } \\
\text { utility billing through m-billing }\end{array}$ & Shop owner & Highly educated \\
\hline Retailer 11 & $\begin{array}{l}\text { Shop (in a district town) for mobile recharge \& } \\
\text { utility billing through m-billing }\end{array}$ & Shop owner & Lower educated \\
\hline Retailer 12 & $\begin{array}{l}\text { Shop (in a rural area) for mobile recharge \& } \\
\text { utility billing through m-billing services }\end{array}$ & Shop owner & Lower educated \\
\hline Retailer 13 & $\begin{array}{l}\text { Shop (in a rural area) for mobile recharge \& } \\
\text { utility billing through m-billing services }\end{array}$ & Employee & Lower educated \\
\hline
\end{tabular}

Highly educated: Bachelor or above

Moderate educated: Between year 8 and year 12

Lower educated: below year 7 


\subsection{Lack of literacy-One of the major barriers to m-commerce adoption}

Although the lack of literacy is not a big challenge for mobile phone adoption in Bangladesh, it was noted by a number of interviewees as one of the biggest barriers to rapid uptake of mobile banking and other m-commerce services in this country. They were asked why lack of literacy is seen to be the major barrier to m-commerce adoption. Some reported that the skill of illiterate people, being limited to receiving and sending a call, restricts them from engaging in m-commerce activities.

\section{"Literacy is the main barrier to using m-commerce service."-Telco 5}

"But in case of mobile banking literacy is required as the customer should be able to read the SMS. Forget about English SMS, how many people can read Bangla? Also when they will be asked to enter their password, will they be able to enter that without the help of any one? That is a question and it needs some research to get a solution of it." - Banker 2

It's been acknowledged that illiteracy can't be removed from the country quickly but there is a way for illiterate people to get the maximum benefit from $\mathrm{m}$-commerce services. One possible solution is the Customer Care Point (CCP), highly used in Bangladesh by both literate and illiterate people. Customer Care Points (CCP), are spread like mushrooms in Bangladesh, helping customers to pay their utility bills through mobile phone with a small charge.

"To be honest $90 \%$ customers are still paying through our outlets (CCP). It's no matter the customer is educated or not and it's because of convenience and tradition." - Telco 2

"But does really an individual paying his bill from his mobile phone? No he goes to the Customer care point or outlet of that mobile company and pay cash to that outlet people and those outlet people are paying the bill on his behalf from their own mobile phone." - Banker 1

Customer care point might be a solution for integrating illiterate people with m-commerce services such as m-billing, m-ticketing and m-remittance, but might not be sufficient for mobile banking which requires a higher level of literacy to maintain the confidentiality of the account details.

"But mobile banking is not that simple.............. you know confidentiality has to be maintained when someone doing mobile banking, such as his password, his account details which must not be compromised to third party such as agent." - Banker 1

It has become clear that low literacy levels have been recognized as among the major barriers to $\mathrm{m}$-commerce adoption in Bangladesh because a reasonable level of literacy is required to read an SMS and use the keypad for various m-commerce services. Although customer care points (CCP) have been widely used by both literate and illiterate people in Bangladesh, they are not suitable for conducting mobile banking services as an individual's password and account details can't be disclosed to a third party. That means illiterate people need to use this confidential information by themselves without the help of CCP or others, obviously a hurdle for them. From the stakeholder's point of view, the illiterate population remains a great potential $\mathrm{m}$-commerce market in Bangladesh as they are the majority, and many of them are already using mobile phone. It is therefore hoped that soon a compatible and comfortable solution will be provided for illiterate people to integrate them into various $\mathrm{m}$-commerce services.

\subsection{Perceived risk}

Previous studies had identified perceived risk as one of the major factors affecting m-commerce adoption negatively, although the current study found risk to be lower in Bangladesh from stakeholder's perspective. In Bangladesh stakeholders are well aware of the negative impact of risk in m-commerce adoption and considered this issue as high priority, but remained confident of the security and privacy of the mobile network. They believed that the mobile network of Bangladesh is secure enough to prevent any loss or fraud in monetary transactions, and also to protect the confidentiality of the user.

\section{"Actually security is a big issue for any financial network." - Banker 1}

"Fully secured. Security is our first priority that's why we are upgrading our software and hardware equipments.... and obviously all the SMS will be encrypted." - Solution provider 2

"This infrastructure is secure enough for mobile banking. Already Bangladeshi mobile operators are handling lots of money through this infrastructure." - Solution provider 3

The existing literature on m-commerce or e-commerce adoption views risk purely from the technical point of view, where the consumers were found to perceive that the mobile network is not 
sufficiently secure to prevent any loss of confidentiality and/or money (see Refs. 34, 72-75). As the technological risk is high in m-commerce adoption, with costs of $£ 1$ trillion annually due to cybercrime, ${ }^{76}$ the interviewees mainly considered risk from the technological point of view overlooking other issues of risk such lack of trust and poor business practices. These will be discussed separately in the next section.

The technology employed and its security features are beyond the scope of this study. It can be assumed that the mobile network in Bangladesh is as technically secure as those in developed countries as internationally recognized telcos are behind the operation and development of this network, implementing the same technology as in developed countries. From the stakeholder's perception, the mobile network of Bangladesh is secure enough to conduct any monetary transactions without compromising confidentiality. However this study does not reflect consumer's perception of risk that may be different than the perception of the providers.

\subsection{How trustworthy the telcos are}

Almost all the interviewees were impressed with Bangladesh Bank and the Bangladesh Telecommunication Regulatory Commission (BTRC), the major government bodies regulating $\mathrm{m}$-commerce services and industries in Bangladesh. No question or suspicion was raised about the trustworthiness of banks who have long been serving the customers in Bangladesh. The only provider of $\mathrm{m}$-commerce that received complaints (mostly minor) from the participants was a telco. Telcos may be trusted in the security of their network, but how trustworthy are they in their business, especially while dealing with the customers for mobile financial services? As reported by some interviewees

"How can I trust them (telcos) that they won't disclose my transaction details; because the payment information will be stored at the telco's server and telco's staff can access them? They could provide that information to third parties if they have a close tie with them or if sufficient amount of bribe is given. You know I can retrieve your call history from your mobile operator just by paying some money." - Retailer 1

"The trust we had in the mobile operators is already sliding down, now if we open the windows for doing financial business as well then the rest of the trust will have to be sacrificed." - Solution provider 3
"But they (telcos) don't want to share the risk; they only want to share the profit". - Govt. official

Telcos need to buildup trust by providing excellent customer service. Some participants seemed to have lost their trust on telcos due its poor customer service, as reported

"I moved from Post paid to prepaid service because of unexpected billing from GP (Grameen Phone), but even the prepaid is also eating you fast." - Retailer 2

"As you know that their (telcos) customer service is not free. On top of that you can't reach them until a long paid waiting, and once you reached them they started to behave unprofessional, rude then how do you feel that." - Retailer 3

The allegations against telcos were not investigated to determine their validity as that was not within the scope of the current study. The objective was to see how those different perceptions and beliefs affect $\mathrm{m}$-commerce adoption in Bangladesh. Some major stakeholders do not recognize telcos as trustworthy enough when dealing with mobile financial services. Their past business experience with the telcos has led them to think this way. Trust needs to be built up by the telcos to enhance confidence among the users and other stakeholders. Assurance of technological security alone will not build up that trust; it needs professionalism in doing business such as excellent customer service, ethical business practice and reputation. When all of these are in place, users and other stakeholders will be in a position to place their trust in telcos to achieve the expected goal.

\subsection{Telco-led vs. Bank-led mobile banking}

Today the model of mobile banking has become another important issue among the stakeholders of $\mathrm{m}$-commerce in Bangladesh, especially between the mobile operators and the banks. Telcos are the pioneers of mobile financial services in Bangladesh. They are giving backend support to the bank's SMS banking, which is a kind of information based mobile banking. As a result they want to lead mobile banking in Bangladesh. Although none of the telcos drew attention to this stand-off in their interviews, it was raised by bankers, solution providers and the government official.

"They still believe and dream in telco led model
mobile banking in Bangladesh"-Govt. official

Bangladesh Bank intervened to resolve the conflict 
by imposing clear and strict regulations that favored the banks, i.e. adopting a Bank-led mobile banking model. Telcos will get a fee for the use of their network but will not receive any share in the revenue generated by mobile banking. The Governor of Bangladesh Bank made it clear that mobile banking in Bangladesh would be a Bank-led model and that the both parties must obey the ruling to run their businesses seamlessly.

"And you know that Bangladesh Bank governor already announced clearly that mobile banking in Bangladesh would be a Bank-led model not Telcoled. So definitely they have to comply with this regulation to run their business." - Solution provider 2

How far the telcos will cooperate with the banks in Bank-led mobile banking is yet to be seen, and some interviewees expressed their reservations about it. Their reasoning is that the telcos are one of the most powerful stakeholders of $\mathrm{m}$-commerce in Bangladesh who might defy or express their dissatisfaction by providing limited or no access to their network. They have done this in the past and are still limiting access on some occasions, which raised questions from the interviewees about their willingness to comply with regulations. As noted by some of the interviewees

"Although we are saying that mobile banking would be a Bank-led model but you know telco's are still not giving access in many cases and it's a big problem." - Govt. official

"From my experience I'm in doubt as to whether the mobile operators will cooperate with the banks for implementing mobile banking." - Solution provider 3

These suspicions and the potential non-cooperation from the telcos may lead the stakeholders and government to rethink the Bank-led model and advocate for a mixed model where the banks and the telcos will share the revenue. This mixed model could help to resolve the conflict between the parties. Some banks and even the authorized bodies of the government have agreed to work towards this co-operative model, indicated as follows

"But in such case the two parties, for example a bank and a mobile operator make mutual deal where bank agree to give some share to the operator then we don't stop them. In that case it could be a telco led model or mix model." - Govt. official

From the above analysis a few things have become clear. First, the model of mobile banking adopted, has been decided as Bank-led model by Bangladesh
Bank. Secondly this decision has been accepted as legitimate by the interviewees since the telcos are reluctant to take any liabilities or risks in mobile banking. Thirdly, the stakeholders of m-commerce such as bankers, solution providers and government officials are still not confident of the success of Bank-led mobile banking due to the potential noncooperation from the telcos. Telcos are suspected of being unreliable because of their past attitude where some stakeholders experienced limited cooperation or non cooperation from them when something went against their (telcos) interests. Telcos have wanted to lead mobile banking in the past, and this desire may have not yet been dispelled. They might defy regulations that are unfavorable to them by not fully cooperating with the stakeholders. For this reason some stakeholders advised for the mixed-model of mobile banking, where the telcos and the banks work as partners and share the revenue is the most likely to succeed.

\subsection{Perceived Cost}

Perceived cost was hypothized to be a barrier in many studies, and its effect was also found to be significant in some countries. The current study focused on this issue by posing a question, asking to what degree cost influences the user's intention to use $\mathrm{m}$-commerce. The cost includes the average price of a mobile phone as well as the access fee for using various m-commerce services such as m-billing, m-ticketing, etc. The average cost of using m-commerce service was found to be affordable by the mass population of the country, as reported

"The price (mobile phone set) could be in between 1300 to 1900Tk ( \$16-\$22) by which you can perform your all mobile financial activities." - Telco 4

It (mobile phone set) could cost between 1100Tk to 1500Tk ( \$15-\$20)." - Telco 3

"It (fee for m-billing) is the market standard, 5Tk ( \$0.06) for up to the bill 400Tk, 10Tk for between 401 to 1500Tk, 15TK for between 1501Tk to 5000Tk and 25TK ( \$0.3) for over 5000Tk." - Telco 4

"I think it is affordable by the lower income people even though we charge between 5Tk to 25Tk ......people still think our service is cheaper than banks." - Telco 2

From these and other comments, clearly the average cost of a mobile phone in Bangladesh that is compatible with m-commerce service ranges from $\$ 15$ to $\$ 22$, equivalent to the world's cheapest 
phone, at below $\$ 15$ launched by Vodafone in $2010{ }^{65}$ The service fee is also not seemed to be very expensive. For example, the access fee for $\mathrm{m}$ billing ranges from $\$ 0.06$ to $\$ 0.3$ and is reported to be affordable by the majority of the people of Bangladesh, whose GDP per capita (PPP) is $\$ 1700$. $^{66}$ The stakeholders believe that the negative effect of cost in the adoption of m-commerce is minor in Bangladesh.

\subsection{Government regulation}

'Bangladesh Bank' (BB) and the 'Bangladesh Telecommunication and Regulatory Commission' (BTRC) are the two major government bodies that regulate the stakeholders of mobile commerce. Telcos and banks do expect cooperation and a positive response from these two authorities. Most of the interviewees expressed their satisfaction when asked about the cooperation they often receive from these two government bodies.

"Bangladesh government is doing very good job. BTRC is also very cooperative. Bangladesh Bank is also slowly opening up." - Telco 1

"I would say government is more positive now than ever before on digitalization... They are also very active and positive." - Telco 2

"So far I think they (BB \& BTRC) are cooperative enough because as soon as I convince them about any new product they respond quickly." - Telco 3

"Yes, I think they (BB \& BTRC) are very cooperative and positive that's why we have done that much until today." - Telco 4

It is apparent that Bangladesh Bank has the right to make a final decision on $\mathrm{m}$-commerce services in Bangladesh, and almost all the interviewees were found to be positive and impressed with the activities of Bangladesh Bank. Bangladesh Bank has the authority to resolve any dispute by regulating the mobile financial services. For example, recently Bangladesh Bank resolved the debate between Telco-led vs. Bank-led mobile banking by making the final decision in favour of the banks, meaning it would be a Bank-led model. The types of business that can be conducted by the banks through mobile phones have also been determined by Bangladesh Bank. These are almost anything but not $\mathrm{P} 2 \mathrm{P}$, person to person mobile transaction, which has yet to be approved.

"Bangladesh Bank has given the permission for mobile banking only to the banks not to the telcos." - Banker 2
"And you know that Bangladesh Bank governor already announced clearly that mobile banking in Bangladesh would be a Bank-led model not Telcoled." - Solution provider 2

"At present person to person fund transfer in mobile banking has not been approved by Bangladesh Bank yet. It can be done but not person to person but from business to person, govt. to govt. or govt. to business. For example, salary or wages can be paid to the employees through mobile phone." - Banker 1

There is some evidence to suggest that the majority of the stakeholders are satisfied with the way $\mathrm{m}$-commerce business is regulated by the government. Bangladesh Bank has made some progress in the field of $\mathrm{m}$-commerce regulation and is thought to be proceeding to the right direction. The second government body, Bangladesh Telecommunication and Regulation Commission (BTRC), is also cooperative and positive according to most interviewees. The Bangladeshi Government, like other governments of third world countries, is seen as being a bit slow and sometimes stuck in the middle. While it may be quite obvious that government needs to do a lot for launching fully fledged m-commerce services, it appears to be moving towards that goal slowly.

\subsection{Others factors - not considered as barriers}

During the face to face interview the participants were asked open ended questions regarding the barriers to m-commerce adoption in Bangladesh. The motive was to get their own perception spontaneously, and caution was taken so that they were not biased by the interviewer's view. The interviewer's own opinion, based on the results of the literature review, was presented to them later at the interview to facilitate discussion. In most cases they seemed to support their own arguments and justify why some factors although found to be barriers to m-commerce adoption in other countries, were not seen as such in Bangladesh. Sometimes they agreed with the interviewer's view that some factors also have a big impact in the adoption of m-commerce in Bangladesh, but seemed to be confused not recognizing them as barriers, but rather calling them positive factors. Examples of some factors are perceived usefulness, perceived ease of use, speed, quality and knowledge which were found to have a positive influence on m-commerce adoption in previous studies.

"Knowledge is a precondition for m-commerce adoption rather as a factor or barrier."- Govt. official 
"We get proper training from telcos so found them (m-billing and m-remittance) easy to use. Also customer's think it is useful otherwise why would they use it?" - Retailer 4

"Obviously these (usefulness and user friendliness) are very important for any new technologies. But when you talk about barriers then that do not sound appropriate for these cases. Barrier is something that drags you behind but their (usefulness and user friendliness) job is to push you ahead." - Solution provider 3

"These (usefulness, user friendliness, speed and quality - in response to the interviewer's query in regard) all are just the characteristics of a product, naturally we must have these things to get the market. But people still lose market even though they have the quality products. Why? Because they do not consider other external factors that could wipeout the market, you can say those as barrier." - Telco 4

In conclusion the stakeholders have differentiated between positive factors and barriers to $\mathrm{m}$ commerce adoption. Perceived usefulness, perceived ease of use, speed and quality are the characteristics of a product required to gain access to market. In contrast barriers are perceived to have negative impact to the adoption that act as a drawback to that market. The participants realized the importance of those factors and agreed on it's positive impact towards $\mathrm{m}$-commerce adoption, but disagreed in some extent to consider them as barrier. The impact of other factors such as complexity, anxiety, limited capacity and size were perceived to have negative but minimal impact to m-commerce adoption.

\section{Conclusions and Implications}

The current research has investigated some factors of m-commerce adoption not studied previously in the context of Bangladesh, including lack of literacy, the conflict of interest between the banks and telcos as to who should lead mobile banking, along with risk and trust. These factors emerged from the qualitative analysis of this research.

On behalf of the Bangladesh Government Bangladesh Bank (BB) has resolved the conflict by ruling in favour of the banks, meaning Bank-led mobile banking is the preferred adopted model. It is yet to be seen how well the telcos cooperate with the banks and with other stakeholders in this Bank-led model, as some would still prefer a Telco-led model mobile banking.
Lack of literacy was viewed as the major barrier to m-commerce adoption in Bangladesh by the majority of the stakeholders, they noted $\mathrm{m}$ commerce in Bangladesh is SMS based, and customers need to be able to read and write to use SMS to conduct any m-commerce services. However the reality for most Bangladeshi customers is that they are not accessing $\mathrm{m}$ commerce services independently, but through the customer care points (CCP) which are spread whole over the country. The role of the CCPs may overcome the barrier to m-commerce adoption in Bangladesh presented by illiteracy. Other barriers to $\mathrm{m}$-commerce such as perceived risk, lack of knowledge, government regulation and cost were also raised by the participants, but these were not considered to be significant barriers to the adoption of m-commerce in Bangladesh.

\section{Limitation and future research}

This research is neither a technical paper of $\mathrm{m}$ commerce nor does it discuss the government policies or regulations; rather the adoption behavior of this technology is studied across a wide range of population of a developing country. Secondly, although Bangladesh has been selected as an example of developing country, what works in Bangladesh may not be universally transferable to other developing countries. Thirdly, smart phone and iPad technologies were not considered as mediums of m-commerce in this research, as these were widely adopted only after this research had commenced.

It would be interesting to study the link between personal awareness of $\mathrm{m}$-commerce and media advertising to see the effectiveness of advertising in raising m-commerce awareness. Another perspective would be to investigate how a company's performance, growth, reputation, solvency and profitability can affect the adoption of m-commerce. These factors were, however, beyond the scope of this research project.

\section{References}

1. J. Zhang and Y. Yuan, M-Commerce Vs ECommerce, Key Differences. Americas Conference on Information Systems (AMCIS),2002 pp.18911901.

2. A. Smith, Exploring m-commerce in terms of viability growth and challenges. International Journal of Mobile Communication, 4(6) (2006) pp.682-703.

3. H. Feng, T. Hoegler, and W. Stucky, Exploring the Critical Success Factors for Mobile Commerce. 
Proceedings of the International Conference on Mobile Business (ICMB'06), (2006) pp.1-8.

4. Gartner Research, The future of payments, viewed on $9^{\text {th }}$ April 2013,

www.pymnts.com/assets/Uploads/The-Future-ofPayments.pdf

5. Juniper Research, Press release of Juniper Research, Viewed on $9^{\text {th }}$ January 2013 on http://www.juniperresearch.com/viewpressrelease.p $h p ? p r=249$

6. M. A. Srivastra, D. R. Tassabehji and D. J. Wallace, Incorporating M-Commerce into Organizational Strategy- case study tourism sector. Working Paper Series, (2008) pp.1-20.

7. Forester Research, Market overview - Mobile commerce solutions for retail, viewed on $9^{\text {th }}$ January 2013 http://www.forrester.com/Market+Overview+Mobil $\mathrm{e}+$ Commerce+Solutions + For + Retail/fulltext///ERES59095

8. C. Coursaris, K. Hassanein and M. Head, MCommerce in Canada: An Interaction Framework for Wireless Privacy. Canadian Journal of Administrative Sciences, 20(1) (2003) pp.54-73.

9. R. Tiwari, S. Buse, and C. Herstatt, From Electronic to Mobile Commerce: Opportunities through Technology Convergence for Business Services. Asia Pacific Tech Monitor, 23(5) (2006) pp.38-45.

10. ITU (International Telecommunication Union) Statistics on mobile cellular subscriptions. http://www.itu.int/ITU-D/ict/statistics, accessed on 29 th June 2012.

11. C. N. Srivanand, M. Geeta and Suleep, Barriers to mobile internet banking services adoption: An empirical study in Klang valley of Malaysia. The internet Business Review, Issue 1, October 2004

12. B. Anckar, C. Carlsson, and P. Walden, Factors Affecting Consumer Adoption Decisions of mCommerce. 16th Bled eCommerce Conference, (2003) pp.886-902.

13. BTRC ( Bangladesh Telecommunication Regulatory Commission), accessed on $9^{\text {th }}$ April 2013 http://www.btrc.gov.bd/index.php?option $=$ com cont ent\&view $=$ article \&id=681: mobile-phonesubscribers-in-bangladesh-january2012\&catid $=49:$ Telco-news\&Itemid $=502$

14. M. Crabbe, C. Standing, S. Standing and H. Karjaluoto, An adoption model for mobile banking in Ghana. International Journal of Mobile Communications, 7(5) (2009) pp.515-543.

15. J. Lu, C. Liu, C. S. Yu, and J. E. Yao, Exploring factors associated with wireless internet via mobile technology acceptance in Mainland China. Communications of the International Information Management Association, 3(1) (2003) pp.101-120.

16. L. D. Chen, A model of consumer acceptance of mobile payment. Inderscience Enterprises Ltd., 6(1) (2008) pp.32-52.

17. J. Cheong, and M. Park, Mobile Internet acceptance in Korea. Internet Research 15 (2) (2005) pp. $125-140$.

18. L. Leong, Theoretical Models in IS Research and the Technology Acceptance Model (TAM). Idea Group Inc, (2003) pp.1-31.

19. F.D. Davis, User acceptance of information technology: system characteristics, user perceptions, and behavioral impacts. International Journal of Man Machine Studies, 1993 pp.475-487.

20. F. D. Davis, Perceived Usefulness, Perceived Ease of Use, and User Acceptance of Information Technology. MIS Quarterly, 13(3) (1989) pp.319340.

21. M. Pagani, Determinants of adoption of third generation mobile Multimedia services. Journal of Interactive Marketing, 18(3) (2004) pp.46-59.

22. S. Snowden, J. Spafford, R. Michaelides, and J. Hopkins, Technology acceptance and m-commerce in an operational environment. Journal of Enterprise Information Management, Volume. 19 No. 5 (2006) pp. 525-539.

23. S. Taylor and P. A. Todd, Understanding information technology usage: A test of competing models. Information Systems Research, 6(2) (1995) pp.144-76.

24. V. Venkatesh and F. D. Davis, A Theoretical Extension of the Technology Acceptance Model: Four Longitudinal Field Studies. INFORMS, 46(2) (2000) pp.186-204.

25. K. O'Reilly, S. Goode, and D. Hart, Exploring mobile commerce intention: Evidence from Australia. In Communications and Information Technologies (ISCIT), October 2010 International Symposium on, IEEE, pp.1120-1125

26. K. K. Kim and B. Prabhakar, Initial trust and the adoption of $\mathrm{B} 2 \mathrm{C}$ e-commerce: The case of internet banking. ACM SIGMIS Database, 35, 2004 pp.5064.

27. I. M. Klopping, E. Mckiinneyy, Extending the Technology Acceptance Model and the TaskTechnology Fit Model to Consumer E-Commerce. Information Technology, Learning, and Performance, 22(1) 2004 pp.35-47.

28. A. Islam, M. Khan, T. Ramayah, and M. Hossain, The Adoption of Mobile Commerce Service among Employed Mobile Phone Users in Bangladesh: Selfefficacy as A Moderator, International Business Research, Volume 4, No. 2 (April 2011) pp. 80-89.

29. P. Meso, P. Musa and V. Mbarika, Towards a model of consumer use of mobile information and communication technology in LDCs: the case of sub-Saharan Africa. Info Systems J, 15 (2005) pp.119-146.

30. X. Cheng, L. Wang, A comparative study of consumers' acceptance model in mobile-commerce. In Computer Engineering and Technology (ICCET), 2nd International Conference on Computer Engineering and Technology. IEEE, Volume 7 (2010) pp.637-641

31. H. P. Lu and P. Y. J. Su, Factors affecting purchase intention on mobile shopping web sites. Internet Research, 19(4) (2009) pp.442-458.

32. T. T. Wei, G. Marthandan, A. Y. L. Chong, K. B. Ooi and S. Arumugam, What drives Malaysian mcommerce adoption-An empirical analysis. Industrial Management \& Data Systems, 109(3) (2009) pp.370-388

33. N. Jahangir and N. Begum, The role of perceived usefulness, perceived ease of use, security and privacy, and customer attitude to engender customer adaptation in the context of electronic banking. African Journal of Business Management, Volume 2 No. 1 (2008) pp.32-40. 
34. J. Wu and S. Wang, What drives mobile commerce? An empirical evaluation of the revised technology acceptance model Science Direct. Information and Management. 42 (2005) pp.719-729.

35. H. Dai and P. C. Palvia, Mobile Commerce Adoption in China and the United States: A CrossCultural Study. The DATA BASE for Advances in Information Systems, 40(4) (2009) pp.43 - 61

36. J. C. Gu, S. C. Lee and Y. H. Suh, Determinants of behavioral intention to mobile banking. Expert Systems with Applications, 36(9) (2009) pp.1160511616.

37. M. Khalifa and N. K. Shen, Explaining the adoption of transactional B2C mobile commerce. Journal of Enterprise Information Management, Volume 21 No. 2 (2008) pp. 110-24.

38. J. Drennan and L.Wessels, An investigation of consumer acceptance of M-Banking in Australia. In Proceedings of Australian and New Zealand Marketing Academy Conference 2009: Sustainable Management and Marketing.

39. W. G. Chismar and S. Wiley-patton, Does the extended technology acceptance model apply to physicians. Proceedings of the 36th Hawaii International Conference on System Sciences, 2003 pp.1-8.

40. M. Koufaris, Applying the technology acceptance model and flow theory to online consumer behavior. Information Systems Research, 13 (2) (2002) pp.205-223.

41. P. E. Pedersen and H. Nysveen, Usefulness and Self-Expressiveness: Extending TAM to Explain the Adoption of a Mobile Parking Service. 16th Bled eCommerce Conference, 2003 pp.705-717.

42. P. A. Pavlou, Consumer acceptance of electronic commerce - Integrating trust and risk with the technology acceptance model. International Journal of Electronic Commerce, Volume.7 No. 3 (2003) pp.101-34.

43. P. E. Pedersen, Adoption of mobile internet services: an exploratory study of mobile commerce early adopters. Journal of Organizational Computing and Electronic Commerce, Volume. 15 No. 3 (2005) pp.203-222.

44. E. Bigne, C. Ruiz and S. Sanz, Key Drivers of mcommerce adoption: An exploratory study of Spanish mobile users. Journal of Theoritical and Applied Electronic Commerce Research, 2(2) (2007) pp.48-60.

45. J. T. Marchewka and C. Liu, An application of UTAUT Model for Understanding student's perception using Management software. Communications of the IIMA, 7(2) (2007) pp.93-104.

46. D. Gefen and D. W. Straub, Consumer trust in B2C e-commerce and the importance of social presence: experiments in e-products and e-services. Omega, Volume 32 (2004) pp.407-424.

47. X. Luo, H. Li, J. Zhang and J. P. Shim, Examining multi-dimensional trust and multi-faceted risk in initial acceptance of emerging technologies: an empirical study of mobile banking services. Decision Support Systems, Volume 49 No. 2 (2010) pp.222-234.

48. S. Alawadhi and A. Morris, The Use of the UTAUT Model in the Adoption of E-government Services in Kuwait. In Hawaii International Conference on
System Sciences, Proceedings of the 41st Annual. IEEE (2008) pp.219-219.

49. V. Venkatesh, M. G. Morris, G. B. Davis and F. D. Davis, User Acceptance of Information Technology: Toward a Unifined View. MIS Quarterly, 27 (2003) pp.425-478.

50. Z. Chen and A. J. Dubinsky, A conceptual model of perceived customer value in e-commerce: A preliminary investigation. Psychology \& Marketing, 20(4) (2003) pp.323-347.

51. B. J. Corbitt, T. Thanasankit and H. Yi, Trust and ecommerce: a study of consumer perceptions. Electronic Commerce Research \& Applications, Volume 2 No. 3 (2003) pp.203-215.

52. N. Mallat, M. Rossi, V. K. Tuunainen and A. Oorni, The impact of use context on mobile service acceptance: the case of mobile ticketing. Information \& Management, 46 (2009) pp.190-195.

53. A. Molla, P. S. Licker, Perceived e-readiness factors in e-commerce adoption: an empirical investigation in a developing country. International Journal of Electronic Commerce, 10(1) (2005) pp.83-110.

54. P. Verdegem and G. Verleye, User-centered EGovernment in practice -A comprehensive model for measuring user satisfaction. Government Information Quarterly, 26(3) (2009) pp.487-497.

55. P. Mahatanankoon and J. Vila-Ruiz, Why Won't Consumers Adopt M-Commerce- An Exploratory Study. Journal of Internet Commerce, 6(4) (2008) pp.113-128.

56. R. A. Boadi, R. Boateng, R. Hinson and R. A. Opoku, Preliminary Insights into M-commerce Adoption in Ghana. Information Development (ISSN 0266-6669), 23(4) (2007) pp.253-265.

57. B. Anckar, C. Carlsson and P. Walden, Factors Affecting Consumer Adoption Decisions of mCommerce. 16th Bled eCommerce Conference, (2003) pp.886-902.

58. H. Nysveen, P. E. Pedersen and H. Thorbjørnsen, Intentions to use mobile services: antecedents and cross-service comparisons. Journal of the Academy of Marketing Science, 33(3) (2005) pp.330-346.

59. P. S. Bamoriya and P. Singh, Issues \& challenges in mobile banking in India: a customers' perspective. Research Journal of Finance and Accounting, 2(2) (2011) pp.112-120

60. A. Jøsang, R. Ismail and C. Boyd, A survey of trust and reputation systems for online service provision. Decision support systems, 43(2) (2007) pp.618-644.

61. J. A. Hill, S. Eckerd, D. Wilson and B. Greer, The Effect of Unethical Behavior on Trust in a BuyerSupplier Relationship: The Mediating Role of Psychological Contract Violation. Journal of Operations Management, 27(4) (2009) pp.281-293.

62. H. P. Lu and P. Y. J. Su, Factors affecting purchase intention on mobile shopping web sites. Internet Research, 19(4) (2009) pp.442-458.

63. M. E. Duffy, Quantitative and qualitative research antagonistic or complementary' Nursing and Health Care, 8(6) (1986) pp.356-357

64. R. K. Yin, Case study research: Design and methods. Sage Publications, Incorporated, (Vol. 5) 2008.

65. BBC News, Vodafone launch world's cheapest phone, accessed on $6^{\text {th }}$ Jan 2012 , http://news.bbc.co.uk/2/hi/technology/8516079.stm, 
66. CIA Fact Book, accessed on $11^{\text {th }}$ January 2012 https://www.cia.gov/library/publications/the-worldfactbook/geos/bg.html.

67. S. Rotchanakitumnuai and M. Speece, Barriers to internet banking adoption: a qualitative study among corporate customers in Thailand. International Journal of Bank Marketing, 21(6/7) (2003) pp.312-323.

68. T. A. Schwandt, Dictionary of qualitative inquiry. SAGE Publications, Incorporated, 2001.

69. L. T. Carr, The strengths and weaknesses of quantitative and qualitative research: what method for nursing? Journal of Advanced Nursing, 20(4) (1994) pp.716-721.

70. M. Quaddus and J. Xu, Adoption and diffusion of knowledge management systems: field studies of factors and variables. Knowledge-Based Systems, 18(2) (2005) pp.107-115.

71. H. F. Hsieh and S. E. Shannon, Three approaches to qualitative content analysis. Qualitative Health Research, 15(9) (2005) pp.1277-1288.

72. K. Kim and B. Prabhakar, Initial Trust, Perceived Risk, and the Adoption of Internet Banking. Proceedings of ICIS, 2000.

73. S. Laforet and X. Li, Consumers' attitudes towards online and mobile banking in China. International Journal of Bank Marketing, 23 (5) (2005) pp.362-380.

74. E. J. Lee, K. N. Kwon and D. W. Schumann, Segmenting the non-adopter category in the diffusion of internet banking. International Journal of Bank Marketing, 23 (5) (2005) pp.414-437.

75. M. Tan and T. S. H. Teo, Factors influencing the adoption of Internet banking. Journal of the Association for Information Systems, 1es (5) (2000) pp.1-42.

76. P. Reich, Cybercrime, Cyber security, and Financial Institutions Worldwide. Book chapter of Cyber Law for Global E-Business: Finance, Payment and Dispute Resolution. Copyright (C) 2008, IGI Global 